\title{
Will Creative Industries Survive in Industrial Revolution 4.0? An Experience from Batik Tulis Lasem, Indonesia
}

\author{
Ali Roziqin $^{1 *}$, Amaliana Nur Fajrina ${ }^{1}$ \\ ${ }^{1}$ Department of Government Studies, Faculty of Social and Political Sciences, Universitas Muhammadiyah \\ Malang, Malang, Indonesia \\ *Corresponding author. Email: aliroziqin@umm.ac.id
}

\begin{abstract}
The development of industrial revolution 4.0 impacted all aspects of human life. One of the aspects that predicted the future is the use of the internet, which will be increasingly significant in the industrial world. Indeed, this condition impacts the development of Small and Medium Enterprises (SMEs) in Indonesia, including Batik Tulis Lasem industries. Currently, batik entrepreneurs are not only faced with internal problems but also external ones as a result of industry 4.0. The purpose of this article is to explore how local stakeholders develop Batik Tulis Lasem in facing the 4.0 industrial revolution. This article uses descriptive qualitative methods to explain the research phenomenon. The primary data were obtained from observations, focus group discussions, and interviews, while secondary data from official government reports and previous research. The result is to respond to the internet's role in changing business models, and batik industry entrepreneurs take various steps depending on their capacity and management. In terms of governance, the local government issued a legal formal regulating Batik Tulis Lasem as hand-written batik instead of printed or stamped batik and provides facilitation to promote its product. Meanwhile, higher education institutions support the development of Batik Tulis Lasem in terms of management, online marketing training, capital and supporting tools, and patent assistance, such as the Intellectual Property Right (IPR).
\end{abstract}

Keywords: Batik Tulis Lasem, Creative Industry, Industrial Revolution, Local Stakeholders.

\section{INTRODUCTION}

Industry 4.0 has changed companies' management, including the Internet of Things (IoT), cloud computing, big data, digitalization, and cyberphysical structures. It makes business processes more autonomous, streamlined, insightful, and digitalizes their end-to-end business processes to transform the business system of governance [1]. This digital technology transformation has a significant impact on the industrial revolution [2], notably creative industries. Almost all governments in the world pay attention to the growth of the creative industry [3]. For example, China has succeeded in developing creative industry clusters in Shanghai [4] and nationally [5]. Furthermore, in the State of Queensland, Australia [3], 28 countries in the European Union creative industry continue to experience an increase [6]. Meanwhile, in South
Korea, the creative industry has become the Government's central discourse [7].

In the Indonesian context, the creative industry has various meanings across regions [8]. Some emphasize new ideas and knowledge in the industrial process, while others interpret cultural or artistic approaches. It is the same as several studies that debate the meaning of the creative industry [8]; [6]; [7]. Some of Indonesia's creative industries are still on the micro and medium scale or often referred to as SMEs. There are 59 million business units of the total business actors in Indonesia in 2018 [9].

Meanwhile, people who depend on their livelihoods and work in the creative industry reached 16.91 million [10]. The description above shows that the creative industry plays an essential role in the Indonesian economy as a developing country [11]; [12]. The creative industry has a vast scope, both in traditional arts and digital technology and innovation 
[13], which can create new jobs, social cohesion, and economic growth [14]. Creativity is the main asset in

Indonesia consisting of game development and application, architecture, interior design, visual communication design, product design, fashion, film, photography, craft, culinary, music, publishing, performing arts, fine arts, also the television and radio [12]. One of the creative industries under focus in this paper is Batik Tulis Lasem, Rembang Regency.

Amid an uncertain future situation due to the 4.0 industrial revolution, Batik Tulis Lasem artisan needs to make a breakthrough and innovation to survive and develop. Currently, Lasem batik has several internal problems such as product development that is marketed from the input, process, and output [16]; resource constraints [17]. Also the problem of regeneration of the craftsmen. In 2017, there were 120 Batik Tulis Lasem industries with a total number of workers reaching 4,444 . This number indicates that Batik Tulis Lasem can be a potential product [17] in the future with proper handling. At the same point, most of the Batik Tulis Lasem industry is still in the SME category. This condition is undoubtedly a common challenge for all stakeholders, especially for the Rembang Regency government in developing the local economy. Furthermore, in this paper, the author explores how the stakeholders involved in developing and maintaining Batik Tulis Lasem amid the challenge of industrial revolution 4.0.

\section{RESEARCH METHOD}

This research uses a qualitative approach that analyzes both primary and secondary data [18]. The authors obtained primary data through observations, focus group discussions, and interviews with related stakeholders such as government institutions consisting of the Rembang Regency Industry and Trade Service, Rembang Regency Bappeda, Batik Tulis Lasem Entrepreneur Association, and the artisan. Observations were also made by authors, especially for Lasem's homemade batik industry. It aims to see first-hand the management mechanism carried out by Batik Tulis Lasem entrepreneurs from input to marketing. The authors also obtain secondary data from documents, books, statistical data, and previous research, as well as other scientific works relevant to research. The information and data obtained are in the form of numbers or descriptive narratives, such as official government reports, as well as their impact on the the development of the creative industry [15]. There are 16 subsectors of the creative industry in

expansion of employment opportunities and layoffs in the area.

Furthermore, for data verification and validation, the researcher carried out an analysis with an official report from the government and previous studies related to the discussion. The phenomena encountered by researchers in the field was analyzed using data reduction and presentation to limit and focus on important matters that were key words in each interview result such as informants and Batik Tulis Lasem developer. The aim was to have a more structured and detailed research . Finally, conclusions were drawn to produce the discussion's narrative.

\section{FINDINGS AND DISCUSSION}

Assuming the 4.0 industrial revolution, it is interesting to note its predecessors and the history of the manufacturing and industrial sectors in general [19]. The high improvement level of technology use in the industrial revolution era has enormously increase complex impacts and challenges on each of its developments, especially in the technological, knowledge, political, social, and economic aspects [20]. The industrial revolution 4.0 has a positive impact on industry actors and a tough challenge for the SMEs actor. It is prone to occur in developing countries with the least mastery level of technology and inadequate infrastructure, such as Indonesia.

The industrial revolution 4.0 has changed the economic strategy to be completely digital [21]; [22]. Direct or indirect use of technology, information, and communication in the industrial world will result in super-fast, exponential, and disruptive changes. So it is feared that the disruptive changes generated by industry 4.0 could gradually erode the old industrial market by producing new industries and new actors with new business models and value propositions [23]. Industry actors need to know their business ecosystem as a digital ecosystem [24]. At the same point, Batik Tulis industry actors need to adapt and change their business ecosystem to survive and develop amid increasingly fierce industrial competition. 


\subsection{The Change of Business Model}

The theory of business models has overgrown over the past two decades, with strong interest from authors and business leaders. In promoting business model developments in various industries, digital technologies play a critical role [13]. Like it or not, a change in the business model is a prerequisite for Lasem's batik industry actors in developing their business. Optimizing information communication and technology in accelerating production, service, distribution, creating market needs, and increasing productivity is a benchmark for success in running a business [25].

The results show that most of Lasem's batik industry has not changed its business patterns and models much. The majority of them still maintain a conventional business from the business networks they have created. An example is the batik brand Pusaka Beruang (Figure 1), which has a large showroom, which actively participates in exhibitions, and has an extensive business network. However, the interesting fact remains that Batik Tulis Lasem industry actors who are still relatively new (business period of 0-5 years) use more ICT in their product marketing process. One of them is Samsul Hadi (owner Sekar Gading), he offer his products through marketplaces and E-commerce such as Tokopedia, Bukalapak, Shopee, and others. At same point, he said that his understanding of Ecommerce was inadequate on the available features. So if this is left unchecked, batik industry actors who are also part of SMEs have the opportunity to go out of business.

Fig.1. Showroom of Pusaka Beruang

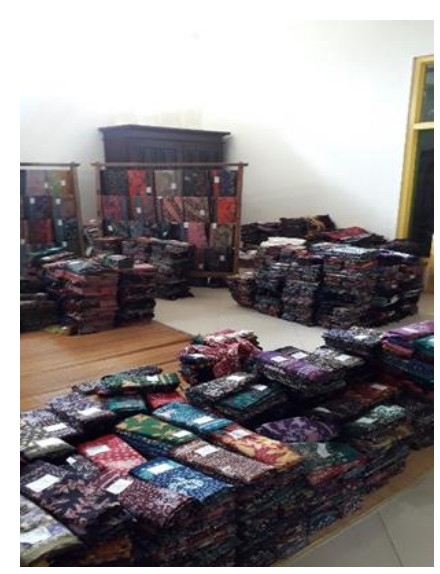

The use of the internet as a new business model provides an important role for batik businessmen, especially if it is done consistently and continuously.
This will certainly encourage an increase in the marketing process, the quantity and quality of human resources, and competitiveness in entrepreneurship.

Considering that Electronic Commerce (Ecommerce) is a part of the e-lifestyle [26], it has a function to make it easier for consumers to communicate, reduce transaction costs via the internet, and ease entry into new markets [27]. The activities of buying and selling goods and services can be done online from any angle and place. Particularly for new batik industry actors, this ecommerce can increase their business's reach to be wider and certainly increase sales turnover.

Furthermore, changing the business model to digital is also a strategic step to face the onslaught of textile products flooding Indonesia's market share. Innovation in the management process and product creativity are two main things that Batik Tulis Lasem industry actors must do. Moreover, the Batik Tulis Lasem industry has contributed to the development of the local economy, which included the processing industry category with $6.9 \%$ in 2017. The batik artisans have spread across several areas of the Rembang Regency. However, Small and Medium Enterprises (SMEs), the Batik Tulis Lasem industry has problems in financial and market access, which is influenced by the capacity to adapt to technological advances [28].

According to the 2019 e-commerce statistical data published by the Indonesian Central Bureau of Statistics, out of 3,504 samples collected from 101 districts/cities in all Indonesian provinces, there are still $84.92 \%$ of businesses that operate without ECommerce. There are several reasons for this, which include feeling comfortable for selling offline $(70.89 \%)$, not interested in selling online $(42.52 \%)$, and lack of knowledge and expertise in using ecommerce (21.78\%). Therefore, collaborative efforts and stakeholder cooperation are needed by Lasem's batik industry to continue to survive and develop.

\subsection{Local Governance for Batik Tulis Lasem}

The creative industry is an industry whose main capital is creativity [15], and Batik Tulis Lasem is one of them. Batik Tulis Lasem has experienced ups and downs in its development process, making it a valuable work that has cultural and philosophical meanings. Moreover, Batik Tulis requires high creativity and innovation in its manufacture. So it requires tenacity and special skills to be able to 
create this commercial value work. As a local creative industry, batik has made a positive contribution to the local economy's development in Rembang Regency. Many people, especially women benefit from the batik industry actors as craftsmen. Moreover, Batik Tulis Lasem is also a cultural heritage that needs to be preserved. However, the majority of batik artisans are the older generation. The younger generation's role is necessary due to regeneration; therefore, it is necessary to have cooperation and local stakeholders' role in providing support both in terms of regulation and management.

Batik Tulis Lasem industry actors believe that digitalization in their business ecosystem will have a positive impact. However, many of the Batik Tulis Lasem industry actors were constrained in its implementation. Supporting the research of Prasetyo [29], the local government has an important role to play in increasing the capacity of the Batik Tulis Lasem industry. Local governments can make topdown [5];[30] and bottom-up planning models [31]. The government can be a key factor in forming a creative society [31] as the primary capital to develop the Batik Tulis Lasem industry is facing the 4.0 industrial revolution.

The Rembang Regency Government, through several related agencies, conducted several programs to develop the Batik Tulis Lasem industry, starting from company management training, bookkeeping, exhibition facilitation, and online marketing. However, due to several limitations, such as human resource capacity and budget, these programs could not reach the entire Batik Tulis Lasem industry, so that the priority is new entrepreneurs.

The Department of Industry, Trade, and Cooperatives are also holding batik promotions to introduce batik to the younger generation. These promotions include exhibitions, batik competitions, to fashion shows of Lasem's handmade batik creations. The Department of Industry, Trade, and Cooperatives collaborate with other OPD (Regional Apparatus Organizations) such as the education office, the cultural and tourism office, and the Regional Arts Council to work together and develop Batik Tulis Lasem. Meanwhile, in terms of support, using ICT for the marketing process, the agency that helps is the Information and Communication Agency.

To preserve and introduce Batik Tulis Lasem to a larger audience, the Regent issued Regent Regulation number 29 of 2017 concerning batik preservation, which has three main objectives, including;

\section{Preserving Batik Tulis Lasem}

2. Preserving the cultural practice of making Batik Tulis Lasem as the cultural wealth of the local community

3. Increasing the living standard of the artisan and society

Through these regulations, Batik Tulis Lasem can be more optimal in supporting the regional economy and can become a medium for public welfare, especially for batik artisan.

Although several attempts have been made locally by local governments, the critical problem is that there are not many adaptive programs facing the era of competition. Batik Tulis Lasem industry needs to prepare for the future industry, it means innovation in the management process is necessary. Otherwise, Batik Tulis Lasem will lose its history books, causing many people to lose their jobs.

\subsection{University or Higher Educational Contribution}

Batik Tulis Lasem, as a creative industry, cannot be separated from the aspects of creativity and knowledge. Industrial revolution 4.0 creates new interaction between humans and machines; therefore, industrial actors need to have Intellectual Capital (IC). However, the current problem is that entrepreneurs' capacity is insufficient to increase creativity and knowledge, both in terms of human resources and infrastructure. Educational institutions, especially tertiary institutions, have a role in increasing industrial actors' management capacity.

Many local creative industries are informal, and only a few have Intellectual Property rights [32]. As part of Intellectual Capital, Intellectual Property Right is an essential asset for industry actors to protect their creativity from plagiarism. so that it guarantees that any idea is original from Batik Tulis Lasem industry actors. Lessons from the UK, today, the creative industry is associated with and characterized by neoliberal values and ideals of flexibility, effort, competition, and modernity [33]. For example, Diponegoro University has assisted in the development of Intellectual Property Right. 
Several universities, such as UNNES (Semarang State University), have helped develop the batik industry's management and infrastructure. One example is UD. Mulya Jaya, owned by Muryati, which received a cooperation grant to improve entrepreneurial management and supporting infrastructure. Meanwhile, local universities such as STIE (School of Economics) and YPPI (Human Potential Development Foundation) also contributed to provide training and promotion to several community groups. There have also been several examples of interaction between academics and the government, namely through collaboration and dedication in the transfer of technology and knowledge to creative developers to achieve targeted achievements in community empowerment. Hence, the local market coverage of Lasem written batik is getting wider. This positive contribution can be a breath for Batik Tulis Lasem industry to continue to survive and develop in the era of the industrial revolution 4.0.

\section{CONCLUSION}

The development of information, communication, technology, and the 4.0 industrial revolution has brought changes to all life sectors globally. Almost every industry uses technology, information, and communication to support business productivity, including creative industries such as Batik Tulis Lasem. The development of information technology has a positive impact to become a tough challenge for batik entrepreneurs, especially since they are mostly classified to be Small and Medium Enterprises (SMEs). Batik industry actors responded in various ways. The majority of business actors adapt by changing their business model by using the internet for marketing although they still have the least technological capacity and knowledge.

Batik Tulis Lasem industry is a local heritage and a specialty of Rembang Regency. To survive and keep growing amidst intense competition, support from several local stakeholders is needed, such as local governments or universities. Moreover, the local government has provided several programs and facilitation, some of which are promotional activities or exhibitions, the regulation concerning Preservation of Batik Tulis Lasem. Meanwhile, higher education institutions help industry actors to increase their company management capacity and provide assistance for online marketing, and helping them with the creation of Intellectual Property Rights to protect the originality of the work in each trademark of Batik Tulis entrepreneurs.
This research implies that batik entrepreneurs are required to increase their capacity for innovation and creativity in all stages of management, especially digital marketing. It also improves the quality of market-oriented products. Mastery of digital marketing and market-oriented will survive or not Lasem's written batik in the era of industrial revolution 4.0.

Based on the conclusions, several issues that need to be accomplished are to improve cooperation among local stakeholders in order to increase the capacity of ICT knowledge for Batik Tulis Lasem industry actors. Moreover, preparing an incubation program for the regeneration of Batik Tulis Lasem artisans is also important. Besides, this paper's implication is to help policymakers at the local level, such as creative industry actors, universities, and local governments, to help create a policy or program in developing the creative industry, with the experience of Batik Tulis Lasem. It is hoped that the 4.0 industrial revolution that we are currently facing will have a positive impact on local economic development.

\section{REFERENCES}

[1] T. Mahmood and M. S. Mubarik, "Balancing innovation and exploitation in the fourth industrial revolution: Role of intellectual capital and technology absorptive capacity," Technological Forecasting and Social Change, vol. 160 , no. June, 2020 , p. 120248. DOI: 10.1016/j.techfore.2020.120248

[2] J. Y. Won and M. J. Park, "Smart factory adoption in small and medium-sized enterprises: Empirical evidence of manufacturing industry in Korea," Technological Forecasting and Social Change, vol. 157, no. May, 2020, p. 120117. DOI: https://doi.org/10.1016/j.techfore.2020.12011 7

[3] R. Daniel, "Policy development and engagement: perspectives and insights from key stakeholders involved in the creative industries in north Queensland, Australia," International Journal of Cultural Policy, vol. 22, no. 2, 2016, pp. 256-272. DOI: $10.1080 / 10286632.2014 .985667$

[4] J. Zheng, “'Creative Industry Clusters' and the 'Entrepreneurial City' of Shanghai," Urban Studies, vol. 48, no. 16, 2011, pp. 3561-3582. DOI: $10.1177 / 0042098011399593$ 
[5] S. Liang and Q. Wang, "Cultural and Creative Industries and Urban ( $\mathrm{Re})$ Development in China," Journal of Planning Literature, vol. 35, no. 1, 2020, pp. 54-70. DOI: $10.1177 / 0885412219898290$

[6] I. Dronyuk, J. Greguš, I. Dronyuk, I. Moiseienko, and J. Greguš, "Analysis of Creative Industries Activities in European Union Countries Analysis of Creative Industries Activities in European Union Countries," Procedia Computer Science, vol. 160, 2019, pp. 479-484. DOI: https://doi.org/10.1016/j.procs.2019.11.061

[7] H. K. Lee, "Politics of the 'creative industries' discourse and its variants," International Journal of Cultural Policy, vol. 22, no. 3, 2016, pp. 438-455. DOI: $10.1080 / 10286632.2014 .991783$

[8] F. Z. Fahmi, P. McCann, and S. Koster, "Creative economy policy in developing countries: The case of Indonesia," Urban Studies, vol. 54, no. 6, 2017, pp. 1367-1384. DOI: $10.1177 / 0042098015620529$

[9] I. Kemenko Perekonomian, "Narasi TunggalLaporan Akuntansi Usaha Mikro," Jakarta, 2018.

[10] Badan Ekonomi Kreatif, "Infografis Ringkasan Data Statistik Ekonomi Kreatif," 2018. [Online]. Available: https://www.bekraf.go.id/berita/page/9/83infografis-ringkasan-data-statistik-ekonomikreatif-indonesia. [Accessed: 07-Oct-2020].

[11] M. Shafi, M. N. I. Sarker, and L. Junrong, "Social Network of Small Creative Firms and Its Effects on Innovation in Developing Countries," SAGE Open, vol. 9, no. 4, 2019, pp. 1-16. DOI: $10.1177 / 2158244019898248$

[12] M. B. Alexandri, E. Maulina, A. Chan, and R. W. S. Sumadinata, "Creative industries: Existence of arts traditional industries in Indonesia," Academy of Strategic Management Journal, vol. 18, no. 1, 2019, pp. $1-12$.

[13] F. Li, "The digital transformation of business models in the creative industries: A holistic framework and emerging trends," Technovation, vol. 92-93, April, 2020, p. 102012.

DOI: https://doi.org/10.1016/j.technovation.2017.12 .004
[14] A. C. Pratt, "The creative and cultural economy and the recession," Geoforum. 2009.

[15] R. Indriartiningtias, Subagyo, and B. Hartono, "Creativity of small firms in creative industry: Initial evidence from Indonesia," International Journal of Engineering Business Management, vol. 11, 2019, pp. 1-13. DOI: $10.1177 / 1847979019849135$

[16] M. Tahwin, D. A. L. Dewi, and A. A. Mahmudi, "Supply Chain Usaha Kecil Menengah (Studi Kasus Industri Batik Tulis Lasem Kabupaten Rembang)," in The 2nd University Research Coloquium 2015, 2015, no. 4, pp. 71-79.

[17] T. Haryono and F. Azis, "Potensi Batik Lasem Sebagai Upaya Pengembangan Ekonomi Kreatif Untuk Meningkatkan Keunggulan Kompetitif Berkelanjutan di Kecamatan Lasem Kabupaten Rembang," Jurnal Ekonomi dan Bisnis Kontemporer, vol. 3, no. 2, 2017, p. 44.

[18] A. B. Hamilton and E. P. Finley, "Qualitative methods in implementation research: An introduction," Psychiatry Research, vol. 280, no. April, 2019, pp. 112516. DOI: 10.1016/j.psychres.2019.112516

[19] F. Moreira, M. J. Ferreira, and I. Seruca, "Enterprise 4.0 - The emerging digital transformed enterprise?," Procedia Computer. Science, vol. 138, 2018, pp. 525-532. DOI: https://doi.org/10.1016/j.procs.2018.10.072

[20] H. Prasetyo and W. Sutopo, "Industri 4.0: Telaah Klasifikasi Aspek Dan Arah Perkembangan Riset," J@ti Undip: Jurnal Teknik Industri, vol. 13, no. 1, 2018, pp. 17-26. DOI: https://doi.org/10.14710/jati.13.1.17-26

[21] G. Valenduc and P. Vendramin, "Digitalisation, between disruption and evolution," Transfer, vol. 23, no. 2, 2017, pp. 121-134. DOI: 10.1177/1024258917701379

[22] A. Issa, B. Hatiboglu, A. Bildstein, and T. Bauernhansl, "Industrie 4.0 roadmap: Framework for digital transformation based on the concepts of capability maturity and alignment," Procedia CIRP, vol. 72, 2018, pp. 973-978, 2018.2 DOI: https://doi.org/10.1016/j.procir.2018.03.151

[23] H. Y. Rahman and Wartoyo, "Implementasi Produksi Dalam Menghadapi Revolusi Industri (Studi Pada Provider di Indonesia)," PROFIT Jurnal Kajian Ekonomi dan Perbankan, vol. 3, 
no. $1, \quad 2018$, pp. 14-29. DOI: https://doi.org/10.33650/profit.v2i2.562

[24] M. Subramaniam, B. Iyer, and V. Venkatraman, "Competing in digital ecosystems," Business Horizons, vol. 62, no. 1, 2019, pp. 83-94. DOI: https://doi.org/10.1016/j.bushor.2018.08.013

[25] A. B. Crittenden, V. L. Crittenden, and W. F. Crittenden, "The digitalization triumvirate: How incumbents survive," Business Horizons, vol. 62, no. 2, 2019, pp. 259-266. DOI: https://doi.org/10.1016/j.bushor.2018.08.013

[26] S. Burt and L. Sparks, "E-commerce and the retail process: A review," Journal of Retailing and Consumer Services, vol. 10, no. 5, 2003, pp. 275-286. DOI: 10.1016/S09696989(02)00062-0

[27] H. Kim, "Globalization and regulatory change: The interplay of laws and technologies in Ecommerce in Southeast Asia," Computer Law and Security Review, vol. 35, no. 5, 2019, p. 105315.

DOI: https://doi.org/10.1016/j.clsr.2019.03.009

[28] Amaliyah, "Business Innovation: Implementation Digital Transformation and Digital Leadership in Era Industrial Revolution 4.0," in 3rd International Conference on Trade (ICOT 2019) Business, 2019, vol. 98, no. Advances in Economics, Business and Management Research, pp. 6-10.

[29] R. Prasetyo, "Peran Pemerintah Daerah dalam Akselerasi Transformasi Digital Industri Kecil dan Menengah Local Government Role in the Digital Transformation," IPTEK-KOM, vol. 22, no. 1, 2020, pp. 59-75. DOI: http://dx.doi.org/10.33164/iptekkom.22.1.202 $0.59-75$

[30] F. N. Aziz and A. Roziqin, "The Perspective of Bureaucratic Reform (Kang Yoto's Leadership) in Bojonegoro," Jurnal Analisis Kebijakan dan Pelayanan Publik, vol. 6, no. 2, 2020, pp. 126-142. DOI: https://doi.org/10.31947/jakpp.vi.10014

[31] Y. Jiang, Q. Qian, X. Zhang, and Y. Chen, "The formation of government-oriented creative community and its driving mechanisms: A case study of the $39^{\circ}$ space art creative community in Foshan, China," Sustainability, vol. 11, no. 3, 2019, pp. 1-20. DOI: 10.3390/su11030625

[32] R. Lobato, "Creative industries and informal economies: Lessons from Nollywood," International Journal of Cultural Studies, vol. 13, no. 4, 2010, pp. 337-354. DOI: $10.1177 / 1367877910369971$

[33] D. Ashton and C. Noonan, "Cultural Work and Higher Education," in Cultural Work and Higher Education, London: Palgrave Macmillan, 2013. 